\begin{tabular}{|c|c|}
\hline 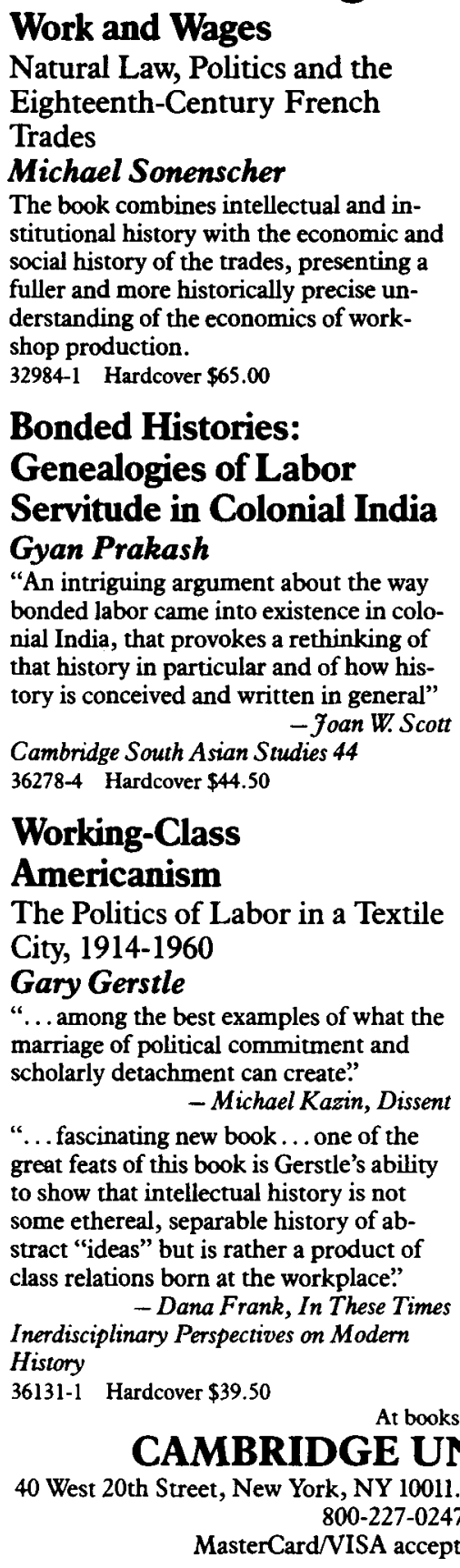 & $\begin{array}{l}\text { Political Change and the } \\
\text { Labour Party 1900-1918 } \\
\text { Duncan Tanner } \\
\text { This book examines the nature of the } \\
\text { Liberal and Labour parties before } 1914 \\
\text { both at the center and in the constituen- } \\
\text { cies. Dr. Tanner discusses the electoral } \\
\text { evidence at length, examines the social } \\
\text { and political changes of war as they influ- } \\
\text { enced politics and offers a reevaluation } \\
\text { of the Labour party's early twentieth } \\
\text { century history. } \\
\text { 32981-7 Hardcover about } \$ 65.00 \\
\text { Russia's Cotton Workers } \\
\text { and the New Economic } \\
\text { Policy } \\
\text { Shop Floor Culture and State } \\
\text { Policy } 1921-1929 \\
\text { Chris Ward } \\
\text { Ward reveals the complex world on the } \\
\text { shop floor of the Russian cotton mill that } \\
\text { grew out of the interaction between the } \\
\text { experience of industrialization in late } \\
\text { 19th and early } 20 \text { th century Russia and } \\
\text { the mechanization of the cotton industry } \\
\text { in late } 18 \text { th and early } 19 \text { th century } \\
\text { Britain. } \\
\text { 34580-4 Hardcover } \$ 44.50 \\
\text { Stalin's Industrial } \\
\text { Revolution } \\
\text { Politics and Workers, } 1928-1932 \\
\text { Hiroaki Kuromiya } \\
\text { "Hiroaki Kuromiya's study of this class } \\
\text { during the first five year plan provides a } \\
\text { penetrating analysis of the political and } \\
\text { social dynamics of Stalinism." } \\
\text { - Times Higher Education Supplement } \\
\text { Soviet and East European Studies } 60 \\
\text { 35157-X Hardcover } \$ 44.50 / 38741-8 \text { Paper } \\
\text { about } \$ 16.95 \\
\end{array}$ \\
\hline
\end{tabular}



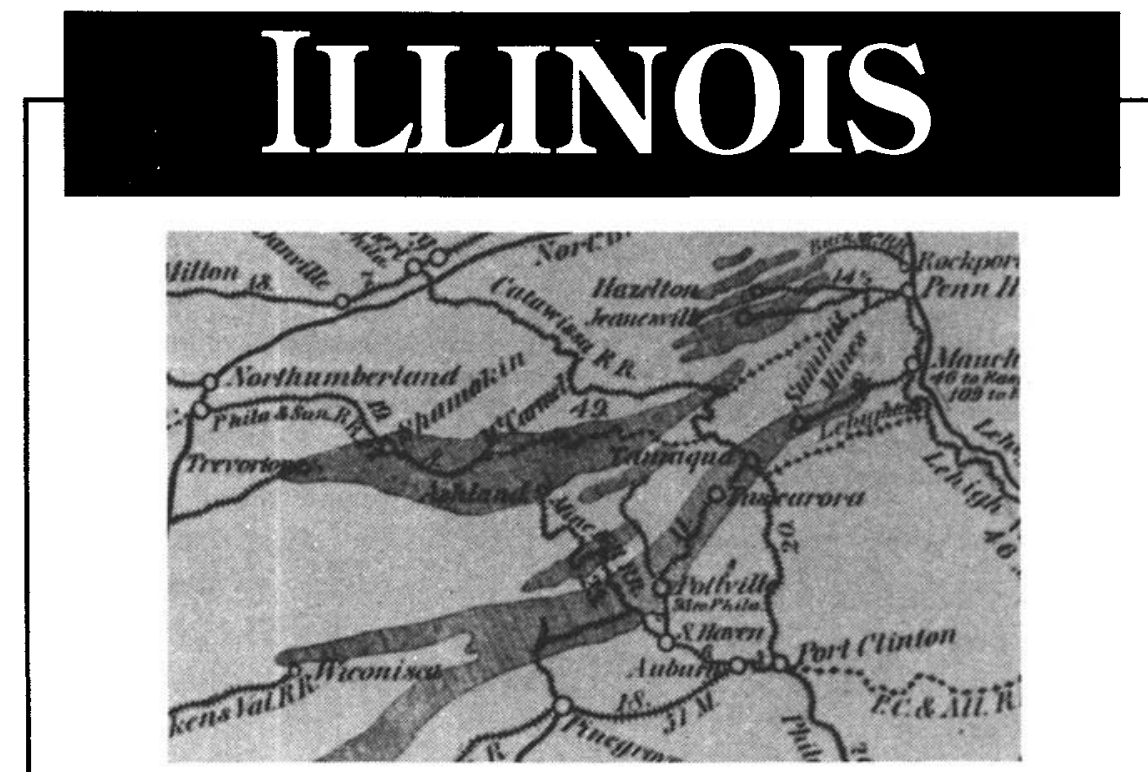

\section{Another Civil War Labor, Capital, and the State in the Anthracite Regions of Pennsylvania, 1840-68 Grace Palladino}

Examines draft resistance during the Civil War era in Schuylkill, Luzerne, and Carbon counties. The use of federal troops to enforce the draft and concurrently suppress labor unrest in these counties marked a significant turning point in federal involvement in local disputes. "Palladino's fine new monograph will force historians to revise their assumptions about Northern unrest during the Civil War. More broadly, it draws attention to the important connections among national politics, military policy, and working class formation in the era before 1877 . Another Civil War is must reading not just for labor historians but for anyone interested in the complex meaning and legacy of the Second American Revolution." - Sean Wilentz, author of Chants Democratic: New York City and the Rise of the American Working Class, 1788-1850. A volume in the series The Working Class in American History. $\$ 26.50$

Order toll free $800 / 545-4703$, or from

University of Illinois Press

P. O. Box 4856 Hampden Pos Office • Baltinore, MII 21211 


\section{Industrial \& Labor Relations Review}

July 1990

Volume 43, Number 5

The Effectiveness of Corporate Campaigns,

1976-1988

Paul Jarley and

Cheryl Maranto

The AFL-ClO Blue Cross-Blue Shield

Campaign: A Study of Organizational Failure

Herbert R. Northrup

Union-Nonunion Differences in Pension

Fund Investments and Earnings

Stuart Dorsey and John Turner

Toward Explaining Early Retirement After 1970

Richard A. Ippolito

Protessionals and Workplace Control:

Organizational and Demographic

Models of Teacher Militancy

Samuel Bacharach, Peter Bamberger, and Sharon Conley

Factors Influencing the Effect of Joint Union-Management Programs

on Employee-Supervisor Relations

William N. Cooke

The Extent and Determinants of

Local Union Control of Participative

Programs

Adrienne E. Eaton

Union Membership and Voting for

COPE-Endorsed Candidates

John Thomas Delaney,

Marick F. Masters,

and Susan Schwochau

Does Centralized Collective Bargaining

Promote Wage Restraint? The Case of Israel

David A. Brauer

Also see our two other regular features: Book Reviews and Research in Progress.

For a limited time, receive free with your new subscription a copy of our special 290-page February 1990 issue, containing fifteen articles on the subject of compensation and firm performance.

Annual rates, U.S. and Canada: $\$ 18$ individual; $\$ 30$ institution.

Foreign, except Canada: $\$ 22$ individual; $\$ 34$ institution.

INDUSTRIAL AND LABOR RELATIONS REVIEW

201 ILR Research Building, Cornell University

Ithaca, NY 14851-0952

(607) 255-3295 


\section{LABOUR/LE TRAVAIL}

\section{JOURNAL OF CANADIAN LABOUR STUDIES}

\section{REVUE D'ETUDES OUVRIERES CANADIENNES}

Labour/Le Travail is the official publication of the Committee on Canadian Labour History. Since it began publishing in 1976, it has carried many important articles in the field of working-class history, industrial sociology, labour economics, and labour relations. Although primarily interested in a historical perspective on Canadian workers, the joumal is interdisciplinary in scope. In addition to articles, the journal features documents, conference reports, an annual bibliography of materials in Canadian labour studies, review essays, and reviews. While the main focus of the journal's articles is Canadian, the review essays and reviews consider international work of interest to Canadian labour studies. Many of Labour's articles are illustrated.

Publiée par de Comité l'histoire du travail du Canada, la revue Labour/Le Travail a fait paraître depuis 1976 plusieurs articles marquants dans le domaine de l'histoire de la classe ouvrière, de la sociologie industrielle, de l'économie du travail et des relations industrielles. Bien qu'elle se propose d'abord d'étudier les travailleurs et les travailleuses du Canada dans une perspective historique, la revue est aussi ouverte aux spécialistes d'autres disciplines. En plus des articles, la revue publie des documents, des rapports de conférences, une bibliographie annuelle, des notes critiques et des comptes rendus de volumes. Si la plupart des articles touchent le Canada, les notes critiques et les comptes rendus portent sur des travaux d'envergure internationale pouv ant intéresser les chercheurs canadiens. Des illustrations accompagnent plusierus articles de Labour/Le Travail.

\section{SPECIAL INTRODUCTORY OFFER/OFFRE SPECIALE}

While the supply lasts, new subscribers may purchase sets of the journal at a special bargain rate of $\$ 200.00$ (24 issues, 7505 pp., reg. $\$ 290$ ).

Avec tout nouvel abonnement, l'abonné peut aussi acquérir la série complète de la revue pour le prix modique de $\$ 200.00$ aussi longtemps que nos réserves de numéros anciens ne sont pas épuisées ( 24 revues, 7505 pp., reg. \$290).

Canada

$\$ 15.00$

$\$ 20.00$

$\$ 12.00$
Foreign/Etranger

Individual/individuel

Institutional/institution

Student/étudiant(e)

Retired/retraité

Unemployed/sans-travail

MASTERCARD accepted or

Make cheque payable to:

Committee on Canadian Labour History

History Department,

Memorial University

St. John's, Nfdl., Canada, A1C 5S7
$\$ 20.00$ (U.S.)

$\$ 30.00$ (U.S.)

$\$ 17.00$ (U.S.)

Carte MASTERCARD acceptée ou

Veuillez faire vos chèque à l'ordre de

Comité de l'histoire du travail du Canada

Départemente d'histoire,

Université Memorial,

St. John's, Nfld., Canada, A1C 5S7

Articles are abstracted and indexed/Les articles sont répertoriés dans:

America: History and Life; Alternative Press Index; Arts and Humanities Citation Index ${ }^{\mathrm{TM}}$, Canadian Magazine Index; Canadian Periodical Index; Current Contents / Arts and Humanities; Historical Abstracts; Human Resource Abstracts; PAIS Bulletin; PAIS Foreign Language Index; Sage Public Administration Abstracts. 


\section{BUILDING BRIDGES}

\section{The Emerging Grassroots Coalition of Labor and Community}

"Fragmented," "isolated"-such terms are often used to describe U.S. social movements today. But over the past few years, onceinsular movements have been reaching out to cooperate at the grassroots level. Building Bridges portrays dozens of the literally hundreds of grassroots coalitions of labor and community groups that have developed over the past few years. It reveals a new, unheralded alignment which promises to transform American society as radically - and far more constructively - than Reagan's New Right coalition did in the 1980s.

Contributors include Jeremy Brecher and Tim Costello, Jim Green, Andrew Banks, Patricia Lee, Jane Slaughter, Peter Rachleff, Barbara Richards, Charles McCollester and Mike Stout, Eric Mann, Bruce Shapiro, Janice Fine, Max Bartlett, Mel Duncan, Michael Pertschuk and Wendy Schaetzel, Cindia Cameron, John Kuo Wei Tchen, Temma Kaplan, Kim Moody, Louise Simmons, John Brown Childs, Staughton Lynd, Daniel Weisman, Mark Ritchie, Carl Boggs, and Jill Nelson.

\section{Edited by Jeremy Brecher and Tim Costello}

\section{$\$ 12.00$ PB7921 paper}

Please add $\$ 1.50$ for the first book, and 50 cents for each additional book when ordering by mail. To pay with MasterCard or VISA, designate which card, card number, and expiration date. $\$ 15.00$ minimum.

At your bookstore or directly from:

MONTHLY REVIEW PRESS

122 West 27th Street, New York, NY 10001

$691-2555$ 


\section{New Paperbacks \\ ILLINOIS}

\section{Work and Community}

in the Jungle

Chicago's Packinghouse

Workers, 1894-1922

James R. Barrett

Winner of the 1988 Illinois State

Historical Society Award of Superior

Achievement

"Barrett has written a first-rate study of Chicago packinghouse workers.... By insisting upon linking community life to the basic power relationship that exists between workers and their employers, he provides a model for community-based working-class history." - Dexter Arnold, Union Labor News. A volume in the series The Working Class in American History. Cloth, \$29.95; paper, \$11.95

\section{Life, Work, and Rebellion in the Coal Fields}

The Southern West Virginia

Miners, 1880-1922

\section{David A. Corbin}

Winner of the 1982 W. D. Weatherford Award

"The coal miners of southern West Virginia have found a historian worthy of their militant traditions. Corbin has sifted an amazing quantity and variety of sources to recover West Virginia miners' self-expressed views of their experiences." - Peter Gottlieb, Intemational Labor and Working-Class History. A volume in the series The Working Class in American History. Paper, $\$ 12.95$

\section{Solidarity and}

Fragmentation

Working People and Class

Consciousness in Detroit, 1875-1900

\section{Richard Jules Oestreicher}

"Oestreicher's well-written and extensively researched book is an outstanding study of the Knights of Labor as well as one of the very best of the growing number of community studies of working-class life that are gradually transforming our understanding of class and community in industrializing America." - Roy Rosenzweig, American Historical Review. A volume in the series The Working Class in American History. Cloth, \$29.95; paper, $\$ 12.95$

\section{Workers, Society,} and the Soviet State Labor and Life in Moscow, 1918-1929

\section{William J. Chase}

"The first detailed account of the working class of Moscow in the "20s - both at work and at home. Chase advances interesting ideas on changing attitudes and behavior of the workers, both in relation to other social groups and to the authorities. His book will provoke thought and further analysis while remaining a solid contribution to an under-researched topic in its own right" - Mary McAuley, author of Politics and the Soviet Union. A volume in the series The Working Class in European History. Cloth, $\$ 34.95$; paper, $\$ 14.95$ 
Issues of International Labor and Working-Class History can be ordered for classroom use. The price per issue to individuals is $\$ 8.00$. For information on discounts for bulkrate sales, write or call the Marketing Manager, University of Illinois Press, 54 E. Gregory Dr., Champaign, IL 61820 (217/333-0950).

\section{Special issues still available}

The Haymarket, Spring 1986, No. 29. Articles by Bruce C. Nelson, Hartmut Keil, Marjorie Murphy, Raymond C. Sun, J. H. M. Laslett, and Hubert Perrier, Catherine Collomp, Michel Cordillot, and Marianne Debouzy.

The Popular Front, Fall 1986, No. 30. Articles by Martha A. Ackelsberg, Herrick Chapman, Irwin M. Wall, Michael Honey, Bruce Nelson, and Gary Cross. Religion and the Working Class, Fall 1988, No. 34. Articles by Michael F. Jiménez, John J. Bukowczyk, Ken Fones-Wolf, and Anna Clark.

DIRECTIONS FOR ILWCH CONTRIBUTORS: An original and two copies of manuscripts are requested. Except for quotations, manuscripts must be in English. All manuscripts must be typed on one side of the sheet only, on $8^{1 / 2} 2^{\prime \prime} \times 11^{\prime \prime}$ nonerasable bond paper, with ample margins. All material-including notes, quotations, bibliographies, tables, and appendixes-must be doubled-spaced. Notes should be grouped together at end of manuscript and should conform to models in the Chicago Manual of Style, 13th ed. If manuscript is prepared on computer, please include a $51 / 4^{\prime \prime}$ or $31 / 2^{\prime \prime}$ diskette in WordPerfect or ASCII format. Maximum length of manuscripts: scholarly controversies, 9,000 words including notes; substantive articles, 9,000 words including notes; thematic essays, 6,000 words including notes; controversy critiques, 2,500 words; review essays, 5,000 words; book reviews, 1,000 words; reports, 1,000 words; letters to the Editor, 750 words. Address manuscripts, correspondence, and books for review to Editor, ILWCH, Center for Studies of Social Change, New School for Social Research, 64 University Place, 4th Floor, New York, NY 10003. Tel. (212) 533-9341.

Authorization to photocopy items for internal or personal use, or the internal or personal use of specific clients, is granted by the Board of Trustees of the University of Illinois for libraries and other users registered with the Copyright Clearance Center (CCC) Transactional Reporting Service, provided that a fee of 10 cents per page is paid directly to CCC, 27 Congress St., Salem, MA 01970. The CCC code for International Labor and Working-Class History (1989) is $0147-5479 / 89 \$ 0+.10$. The rate stated applies to library copying, photocopies placed on reserve, and copying for classroom use beyond the number of copies and frequency permitted by Sections 107 and 108 of the U.S. Copyright Law. For issues with a publication date prior to 1978 there is a uniform fee of 50 cents per copy of an article. Permissions and rates given above do not extend to copying for advertising or promotional purposes or creating new collective works. 


\section{To Appear in Forthcoming Issues of $\mathrm{ILWCH}$}

\section{Scholarly Controversies}

Uses and Abuses of Demography in Working-Class History

David Levine

Responses by John Gillis and William Sewell

Labor and the Welfare State

Essays by James Cronin, George Steinmetz, Michael Hanagan and Miriam Cohen

\section{Review Essays}

Labor and the Cold War

Geoffrey Eley

Women and Domestic Labor

Louise Tilly

Science, Work, and Modernity

Anson Rabinbach 